\author{
Danuta Piróg \\ Zakład Dydaktyki Geografii \\ Instytut Geografii \\ Akademia Pedagogiczna, Kraków
}

\title{
Miejsce i rola edukacji europejskiej w nauczaniu podstaw przedsiębiorczości w kontekście współczesnych wyzwań cywilizacyjnych
}

Zachodzące przemiany społeczne, gospodarcze, kulturowe i polityczne w Polsce i na świecie, zwłaszcza procesy globalizacji i integracji z Unią Europejską oraz postępujący z coraz większym nasileniem rozwój cywilizacyjny, wymuszają na społeczeństwie przygotowanie się do nowych warunków życia. Zasadniczą rolę w tym zakresie odgrywa przyswojenie wiedzy o wymienionych procesach, zrozumienie mechanizmów nimi rządzących i nabycie umiejętności, pozwalających na sprawne funkcjonowanie jednostki w nowej rzeczywistości.

Wspomniane umiejętności są konieczne do opanowania w dobie współczesnych wyzwań cywilizacyjnych. Winny one służyć wypracowaniu określonych kompetencji, a przede wszystkim wypracowania pożądanych przekonań i postaw. Niemal wszyscy doświadczamy, że koniecznym jest nabywanie różnorodnych umiejętności, tj. obsługi komputera, dobrej znajomości co najmniej jednego języka obcego, gotowości do przekwalifikowywania się, doskonalenia zawodowego, sprawnej współpracy w grupie, komunikacji interpersonalnej, tolerancji, gotowości do dialogu itp... Dwie pierwsze spośród wymienionych umiejętności są stosunkowo łatwe do opanowania, bowiem opierają się głównie na zdobyciu określonego zasobu wiedzy i jej praktycznego ćwiczenia aż do osiągnięcia pożądanego standardu. Rozpatrując jednak kompetencje dotyczące relacji interpersonalnych, dotykamy sfery przekonań i postaw, które są znacznie trudniejsze do wykształcenia. Jednocześnie otwartość na innego człowieka, niwelowanie niepożądanych stereotypów, ksenofobii, wyzbycie się kompleksów i niskiej samooceny jest nieodzowne, m.in. w procesie integracji Polski z Unią Europejską.

Obecnie, m.in. dzięki rozwojowi środków komunikacji, integracji, zjawiskiem powszechnym są migracje ludności, a w konsekwencji zanikanie zbiorowości jednorodnych, zwiększanie zróżnicowania etnicznego, religijnego czy kulturowego. Owocna dla Polaków integracja nie może być rozpatrywana wyłącznie w kategoriach współpracy między rządami krajów członkowskich, ale także w kooperacji między obywatelami krajów UE. Procesy zróżnicowania społeczeństw intensyfikują się na całym świecie, w tym w Europie i w Polsce. Wkraczamy więc $\mathrm{w}$ okres wymagający współpracy w grupach bardzo zróżnicowanych, co z kolei jest możliwe, jeżeli członkowie tychże grup będą posiadają wcześniej wymienione cechy osobowościowe.

Efektywność rozwoju i współpracy w społeczeństwach zróżnicowanych jest według K. Błeszyńskiej (2001) uzależniona od:

1) czynników historycznych:

- występowanie lub brak konfliktów zbrojnych pomiędzy rozpatrywanymi krajami; 
- wcześniejsze kontakty z grupami odmiennymi kulturowo poprzez realizowanie wspólnych projektów, wymiany młodzieży szkolnej, studentów i nauczycieli lub brak jakichkolwiek bezpośrednich doświadczeń w tym zakresie.

2) czynników gospodarczych:

- podobny poziom rozwoju gospodarczego i standardu życia ludności lub znaczne zróżnicowanie tego poziomu, przejawiające się przede wszystkim w problemach bezrobocia, kryzysie ekonomicznym, niskim standardzie życia.

3) świadomie podejmowanych manipulacji politycznych:

- niezgodne z prawdą zastraszanie społeczeństwa konsekwencjami współpracy, akcentowanie wyłącznie kosztów i marginalizowanie zysków kooperacji lub pokazywanie wyłącznie pozytywnych przykładów współpracy.

4) koncepcji wychowawczych

- wpajanie postaw antagonistycznych, wychowywanie w duchu ksenofobii lub kształtowanie postaw tolerancji, otwartości.

Doceniając wagę i potrzebę kreowania społeczeństwa przygotowanego do skutecznej współpracy na różnorodnych polach w zmieniającym się świecie, nie można pominąć roli szkoły w tym zakresie. Naczelnym celem kształcenia jest bowiem przygotowanie ucznia do dorosłego życia. Jest to bardzo trudne i ważne zadanie, które stoi przed systemem edukacyjnym, a w praktyce przede wszystkim przed kreatorem procesu kształcenia, czyli nauczycielem. Chcąc sprostać wymienionym zadaniom, należy poszukiwać realnych dróg optymalizujących osiągnięcie założonych celów.

Niwelowaniu niechęci, antagonizmów, obaw i wypracowywaniu postaw otwartości oraz gotowości do współpracy może służyć rzetelna realizacja wielu przedmiotów szkolnych przez kompetentnych nauczycieli. Według Z. Zioło (2002) geografia jest przedmiotem szkolnym, który posiada znaczący potencjał w tym zakresie na wszystkich szczeblach edukacyjnych, bowiem jego istotą jest łączenie zagadnień społecznych, gospodarczych i politycznych, określanie relacji między nimi w różnej skali układów przestrzennych. Podkreśla on, że przygotowanie merytoryczne społeczeństwa na niższym poziomie rozwoju musi być szersze, bowiem tylko w taki sposób można skutecznie odbierać i przetwarzać impulsy rozwoju cywilizacyjnego i wzrostu gospodarczego.

Nadto, jak wynika z analizy podstaw programowych kształcenia ogólnego, ogniwem predestynowanym do efektywnego osiągania naczelnego celu kształcenia, czyli przygotowania ucznia do dorosłego życia wymiarze jednostkowym i zbiorowym $\mathrm{w}$ dobie intensywnych przemian cywilizacyjnych jest nauczanie przedmiotu podstawy przedsiębiorczości i realizowanie międzyprzedmiotowej ścieżki Edukacja Europejska.

Autorka niniejszej publikacji stawia tezę, iż majoryzowanie treści z zakresu edukacji europejskiej w cyklu kształcenia szkolnego, jak również rzetelne, pogłębione realizowanie tematyki europejskiej przez nauczycieli przygotowanych do nauczania podstaw przedsiębiorczości, daje szansę przygotowania ucznia do poznania, zrozumienia i właściwego odniesienia do współczesnych wyzwań cywilizacyjnych.

Docenienie roli i zasadności akcentowania tych treści w procesie kształcenia jest teraz szczególnie ważne, bowiem obecnie, po 1 maja 2004 roku, praktyczne wykorzystanie wiedzy i umiejętności, wyniesionych $\mathrm{z}$ zajęć szkolnych przez ucznia w życiu codziennym $\mathrm{w}$ coraz to większym stopniu będzie musiało nawiązywać do norm i zasad unijnych. W okresie integracji polskiej gospodarki z gospodarką Unii Europejskiej konieczne jest poznanie mechanizmów, warunków i zasad funkcjonowania tej organizacji. Zaznajomienie się z procesami gospodarczymi zachodzącymi w krajach UE pozwoli ocenić szanse i zagrożenia, jakie wynikają z faktu wejścia Polski do tej organizacji. (Makieła Z., 2004).

Uzasadnianie postawionej tezy wymaga ustalenia znaczenia terminu edukacja europejska. Jak wynika $\mathrm{z}$ analizy dawnych programów nauczania zagadnienia europejskie $\mathrm{w}$ polskich szkołach były obecne co najmniej od XVIII wieku (Lipko S., 1973). Przez długie lata skupiały się przede wszystkim na geografii politycznej i historii Europy. Uczniowie 
mieli w ten sposób szansę poznania środowiska geograficznego, genealogii rodów panujących, wybranych faktów historycznych, niektórych języków obcych, elementów wiedzy z zakresu sztuki i polityki Polski i Europy. Edukacja taka kreowała często dualizm Europy i Polski, bez wskazywania na wzajemne związki i podobieństwa. Dla większości społeczeństwa stereotyp ten jest do dziś oczywisty. Stąd królują stwierdzenia typu: ,idziemy do Europy”, „Polska w drodze do Europy” zamiast ,jesteśmy w Europie”, ,jesteśmy Europejczykami".

Rzetelne nauczanie-uczenie się geografii, historii Europy czy języków obcych jest bardzo potrzebne, ale nie daje optymalnego przygotowania ucznia do życia w nowych społeczno-gospodarczych warunkach zjednoczonej Europy. Oprócz wiedzy, a może nawet bardziej niż wiedzy, uczeń potrzebuje wyzbycia się kompleksów, uprzedzeń, stereotypów. Uczeń powinien utożsamiać siebie jako obywatela swej wsi, miasta, kraju oraz kontynentu, mieć kulturę osobistą zapewniającą swobodne współbycie z obywatelami innych krajów.

Wymienione potrzeby wykraczają poza ramy przedmiotów szkolnych i dlatego w krajach Unii Europejskiej wytworzyła się, a w polskim szkolnictwie krystalizuje się, tak zwana edukacja europejska, zwana także wymiarem europejskim bądź europeizmem.

Termin edukacja europejska $\mathrm{w}$ dziedzinie edukacji pojawił się po raz pierwszy w Rezolucji Rady Ministrów Edukacji WE z 9 lutego 1976 r. W dokumentach Unii jego odpowiednikiem jest „european dimension” - wymiar europejski. (Rabczuk W., 1994). Obecnie termin ten ma wiele znaczeń:

W. Rabczuk (1994) europejski wymiar nauczania rozumie w szerszym znaczeniu jako:

- działania mające na celu wzmacnianie u młodzieży poczucia tożsamości europejskiej;

- dążenie do wyznaczenia szkole i nauczycielowi nowej roli w stosunku do imigrantów, mniejszości etnicznych oraz poszukiwania interkulturalnego modelu kształcenia.

Zaś w znaczeniu węższym jako ,... wzbogacanie szkolnych treści programowych o te elementy wiedzy, które przyczyniają się do rozwijania świadomości europejskiej” (s. 169).

Cz. Banach $(1993,1999,2001)$ wymiar europejski traktuje w kategorii zadań szeroko pojętej edukacji w integracji Polski z UE, koncentrujących się w trzech płaszczyznach:

- jako takie kształcenie ludzi, by prawidłowo realizowali oni zadania integracyjne w życiu;

- jako „edukację uczącą o Europie” poprzez przedmioty szkolne i zajęcia fakultatywne;

- jako „edukację przez Europę”, tj. zdobywanie doświadczeń na drodze obcowania z innymi narodami.

B. Kalinowska-Witek (2000) edukację europejska ukazuje jako zadanie dla wszystkich szczebli kształcenia, polegające na nauczeniu młodych ludzi krytycznego myślenia i gotowości do kształcenia ustawicznego, a rolę nauczyciela określa jako opiekuna czuwającego nad kształtowaniem właściwych postaw uczniów wobec otaczającego ich świata. Autorka podkreśla również konieczność dokształcania nauczycieli, zwłaszcza stworzenia warunków do wymiany doświadczeń z nauczycielami z innych krajów.

M. Sielatycki (1993a, b; 1999; 2000) uważa, iż w ramach edukacji europejskiej powinny być obecne cztery równorzędne elementy:

- uczenie się o Europie

- uczenie się o integracji europejskiej

- „europejskie myślenie”

- „europejskie kompetencje” (znajomość obsługi komputera, języków obcych)

Wyżej zaprezentowane interpretacje wymiaru europejskiego wydają się mieć wspólny mianownik i określać europeizm jako całokształt działań szkoły i innych instytucji, mających na celu edukację o kontynencie europejskim i jego mieszkańcach dla przygotowania ucznia do optymalnego partycypowania we wszystkich sferach życia integrującej się Europy. (Butryn D. 2001). 
Według autorki niniejszej pracy termin edukacja europejska to nauczanie-uczenie się o szeroko pojętych procesach integracyjnych (tj. politycznych, gospodarczych, społecznych, kulturalnych) w Europie oraz kształtowanie postaw otwartości oraz tolerancji wobec innych ludzi.

Obecnie zagadnienia europejskie w polskim szkolnictwie występują na 3 i 4 etapie kształcenia, tj. w gimnazjum i liceum. W gimnazjum tematyka europejska pojawiła się $\mathrm{w}$ rozszerzonej postaci i została zapisana jako obowiązująca na lekcjach geografii, historii, wiedzy o społeczeństwie oraz na międzyprzedmiotowych ścieżkach edukacyjnych :Edukacja Europejska i Kultura polska na tle cywilizacji śródziemnomorskiej. Jak wynika z „Podstawy programowej..." (2001) najszerzej tematyka europejska w gimnazjum powinna być poruszana na lekcjach geografii. W ramach hasła:- „Współczesne przemiany gospodarcze, społeczne i polityczne na kontynentach i w wybranych krajach, ze szczególnym uwzględnieniem Europy" dokonuje się charakterystyki wybranych krajów w Europie. Dodatkowo w 3 klasie gimnazjum geografia Polski omawiana jest na tle kontynentu europejskiego oraz całego świata. Osobny zapis przewiduje rozpatrzenie na lekcjach geografii problemów związanych z szeroko pojętymi procesami integracji, $w$ tym $z$ integracją w Europie. Tu przede wszystkim uczeń powinien zapoznać się z wymaganiami dostosowawczymi Unii, z którymi zmaga się Polska w trakcie negocjacji o wejście jej struktur w ujęciu lokalnym i ogólnokrajowym.

W szkolnictwie ponadgimnazjalnym tematyka europejska powinna znaleźć się na lekcjach geografii, języka obcego nowożytnego, historii i podstaw przedsiębiorczości. W liceum profilowanym w ramach geografii są to następujące zagadnienia: „, Procesy przechodzenia od izolacji do integracji; współpraca między społeczeństwami; procesy integracji i dezintegracji w Europie; euroregiony i miasta (gminy) „bliźniacze” jako przykład współpracy międzynarodowej na szczeblu regionalnym i lokalnym".

$\mathrm{Na}$ zajęciach $\mathrm{z}$ podstaw przedsiębiorczości winny być rozpatrywane treści: „Współpraca gospodarcza Polski z zagranicą. Integracja z UE”. Tak szerokie ujęcie zagadnienia sprzyja indywidualnemu realizowaniu koncepcji tych treści autorom programów i podręczników szkolnych z zakresu podstaw przedsiębiorczości oraz nauczycielom.

Zarówno w gimnazjum, jak i w szkolnictwie ponadgimnazjalnym bardzo istotnym dopełnieniem wymiaru europejskiego jest ścieżka Edukacja Europejska. Ścieżka jest całkowicie poświęcona tematyce europejskiej z dominacją zagadnień UE i procesów integracyjnych (patrz tab. 1)

Ponieważ ścieżki mogą być zarówno wkomponowane w poszczególne przedmioty szkolne, jak i mogą stanowić odrębne zajęcia modułowe, stąd też nauczyciel podstaw przedsiębiorczości powinien dążyć do pozyskania części godzin do dyspozycji dyrektora dla prowadzenia ścieżki Edukacja Europejska w module. Argumentem przemawiającym za celowością ujęcia modułowego ścieżki winna być jakość i efektywność tychże zajęć. Oprócz bliskiego podstawom przedsiębiorczości zakresu treściowego, także i cele stawiane tej ścieżce są zbieżne $\mathrm{z}$ celami edukacyjnymi tego przedmiotu.

Zasadniczym pytaniem, które winien postawić sobie każdy nauczyciel przed rozpoczęciem realizacji edukacji europejskiej brzmi: W jaki sposób edukacja europejska na zajęciach przedsiębiorczości winna być prowadzona, by służyła wykształceniu i wychowaniu ucznia zdolnego do radzenia sobie ze współczesnymi wyzwaniami cywilizacyjnymi? Według autorki niniejszej publikacji całość zagadnień tego przedmiotu szkolnego jest wyraźnie predestynowana do realizowania tego celu. Edukacja europejska może dodatkowo wzmacniać i optymalizować to przygotowanie i wykształcenie człowieka otwartego, twórczego, aktywnego, wyposażonego w konieczny zasób wiedzy i umiejętności jej dalszego pozyskiwania i wykorzystywania. Osiągnięcie wskazanych celów umożliwia właściwa hierarchia celów kształcenia. W świetle badań eksperymentalnych, dotyczących optymalizacji edukacji europejskiej na etapie gimnazjum, czynnikiem determinującym efektywność było uwypuklanie celów wychowawczych, tj. nakierowanie w całym cyklu kształcenia na wypracowanie 
pożądanych przekonań i postaw. Treści kształcenia były jedynie środkiem do osiągania tych celów. (Piróg D.,2003).

Tab. 1. Tematyka ścieżki Edukacja Europejska w szkolnictwie gimnazjalnym i ponadgimnazjalnym

\begin{tabular}{|c|c|}
\hline $\begin{array}{l}\text { Hasła programowe ścieżki Eduka- } \\
\text { cja Europejska w gimnazjum }\end{array}$ & $\begin{array}{c}\text { Hasła programowe ścieżki Edukacja Europejska w } \\
\text { liceum profilowanym }\end{array}$ \\
\hline $\begin{array}{l}\text { 1. Polska w Europie. Przykłady naj- } \\
\text { ważniejszych wzajemnych związków } \\
\text { między Polską a innymi państwami } \\
\text { europejskimi w przeszłości. } \\
\text { 2. Zasady ładu europejskiego opar- } \\
\text { tego na wspólnej, historycznej pod- } \\
\text { stawie cywilizacyjnej: filozofii grec- } \\
\text { kiej, prawie rzymskim i Biblii. } \\
\text { 3. Twórcy Wspólnot Europejskich: R. } \\
\text { Schuman, A de Gasperi, K. Adenau- } \\
\text { er i inni. } \\
\text { 4. Cele i założenia Wspólnot Euro- } \\
\text { pejskich. Krótka historia traktatów. } \\
\text { 5. Wielość koncepcji rozwoju Unii } \\
\text { Europejskiej. } \\
\text { 6. Rada Europejska, Rada Unii Euro- } \\
\text { pejskiej, Komisja Europejska, Parla- } \\
\text { ment Europejski, Europejski Trybunał } \\
\text { Sprawiedliwości, Trybunał Rewiden- } \\
\text { tów Ksiegowych. } \\
\text { 7. Jednolity Rynek Europejski (swo- } \\
\text { bodny przepływ osób, towarów, } \\
\text { kapitału i usług). Waluta europejska. } \\
\text { 8. Polityka edukacyjna Unii Europej- } \\
\text { skiej: między odrębnościa progra- } \\
\text { mową i formami współziałania. } \\
\text { Programy wsółpracy i wymiany } \\
\text { modzieży. Wymienialność dyplo- } \\
\text { mów. Nauka języków obcych. } \\
\text { 9. Proces integracji Polski z Unią } \\
\text { Europejską. Procedury negocjacyjne. } \\
\text { Koszty i korzyści wynikające z człon- } \\
\text { kostwa w Unii Europejskiej dla pol- } \\
\text { skiego obywatela. } \\
\text { 10. Bezpieczeństwo europejskie: } \\
\text { NATO, OBWE, ONZ. } \\
\text { 11. Rada Europy. } \\
\text { 12. Grupa Wyszehradzka. Inne orga- } \\
\text { nizacje regionalne. } \\
\text { 13. Prawa człowieka. } \\
\text { 14. Duchowy wymiar wspólnoty } \\
\text { europejskiej (przesłanie Jana Pawła } \\
\text { II). }\end{array}$ & $\begin{array}{l}\text { 1. Proces integracji europejskiej w perspektywie histo- } \\
\text { rycznej: czynniki integrujące i dezintegrujące. Polska } \\
\text { Polacy w budowaniu jednoczącej się Europy. } \\
\text { 2. Droga państw europejskich, w tym Polski, do UE. } \\
\text { System, procedury i pola negocjacji. Kalendarium roz- } \\
\text { szerzenia. Cele integracji Polski z UE. Przedakcesyjne } \\
\text { działania i programy rządu. } \\
\text { 3. Stosunek społeczeństw krajów członkowskich i spo- } \\
\text { teczeństwa polskiego do rozszerzenia Wspólnot Euro- } \\
\text { pejskich. Różne opcje obecne w polityce i opinii publicz- } \\
\text { nej krajów członkowskich. Katalog nadziei i obaw. Wy- } \\
\text { obrażenie roli i miejsca Polski i Polaków w zjednoczonej } \\
\text { Europie. Kwestia standardów unijnych. } \\
\text { 4. Kierunki integracji. Trzy filary procesu zjednoczenia. } \\
\text { Różne koncepcje wizji przyszłej zjednoczonej Europy. } \\
\text { 5. Ewolucja prawa UE. Kwestia konstytucji UE. Wza- } \\
\text { jemne relacje między prawem UE i prawem krajowym. } \\
\text { 6. Ewolucja instytucji UE. Procedury podejmowania } \\
\text { decyzji. } \\
\text { 7. Gospodarka UE. Polska w perspektywie polityk } \\
\text { wspólnotowych w dziedzinie gospodarczej, w tym w } \\
\text { szczególności wspólnej polityki rolnej. } \\
\text { 8. Jednolity europejski rynek pracy i jego dostępność dla } \\
\text { obywateli polskich. Europejskie problemy społeczne } i \\
\text { sposoby ich rozwiązywania. } \\
\text { 9. Droga krajów członkowskich do Unii Gospodarczej } i \\
\text { Walutowej. } \\
\text { 10. Bezpieczeństwo europejskie w wymiarze międzyna- } \\
\text { rodowym i wewnętrznym. Bezpieczeństwo Polski w } \\
\text { ramach UE i NATO. } \\
\text { 11. Prawa i obowiązki obywatelskie, obywatelstwo eu- } \\
\text { ropejskie, obywatelski wymiar procesu integracji euro- } \\
\text { pejskiej. } \\
\text { 12. Europa wartości. Duchowy wymiar Europy - eduka- } \\
\text { cja, kultura. Rola edukacji jako czynnika wyrównywania } \\
\text { szans polskiej młodzieży w Europie. Możliwości współ- } \\
\text { pracy. } \\
\text { 13. Rola i zasady działania samorządów terytorialnych } \\
\text { w UE. Współpraca polskich samorządów z odpowiedni- } \\
\text { kami z UE. Euroregiony. } \\
\text { 14. Miejsce Polski w organizacjach europejskich, w tym } \\
\text { w Radzie Europy. } \\
\text { 15. Polska i jej sąsiedzi. Polska w regionie Europy } \\
\text { Srodkowej i Bałtyku. Polska i Europa Wschodnia. }\end{array}$ \\
\hline
\end{tabular}

Źródło: Dz. U nr 61 z dnia 19 czerwca 2001 r. 
Posługując się wynikami z przeprowadzonego eksperymentu, można stwierdzić, że realizacja edukacji europejskiej na lekcjach z podstaw przedsiębiorczości i w ramach ścieżki, winna priorytetowo traktować cele wychowawcze (patrz ryc. 1).

Ryc. 1. Realizacja edukacji europejskiej w nauczaniu podstaw przedsiębiorczości
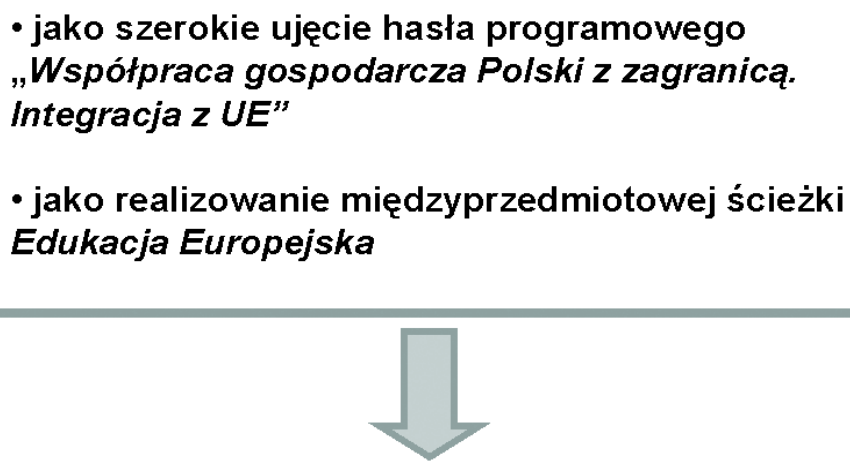

Cele wychowawcze wysunięte na pierwszy plan

I tak, np. w ramach hasła programowego integracja Polski z UE, należy rozważyć zagadnienia Jednolitego Rynku Europejskiego (JRE). Cele kształcące tych zajęć winny być podporządkowane celom wychowawczym, tj.

Uczeń jest przekonany:

- $\quad$ że wprowadzenie swobody przepływu osób przyczynia się do tego, by każdy człowiek czuł się nie tylko obywatelem swego kraju, ale również obywatelem Europy;

- że swoboda przepływu osób i usług może po wejściu Polski do Unii pomóc rozwiązać problem bezrobocia, dać szersze perspektywy ludności, o ile nasze wykształcenie będzie na konkurencyjnym poziomie.

Wskazane cele należy akcentować i eksponować na zajęciach w trakcie realizowania celów kształcących, np.:

Uczeń potrafi:

- wymienić cztery swobody JRE;

- $\quad$ scharakteryzować cechy gospodarki rynkowej w Europie;

- wyjaśnić następstwa utworzenia rynku wewnętrznego dla obywateli i gospodarki UE oraz pozostałych państw w Europie;

- scharakteryzować korzystne i niekorzystne zmiany dla Polski w przyszłości po wejściu do Unii, wynikające z JRE;

- omówić mechanizmy ochrony JRE.

Stosując te samą koncepcję w hierarchizowaniu celów można też rozwinąć zagadnienie współpracy i integracji na poziomie młodzieży szkolnej, wymian uczniowskich, programów wspierających finansowo takie przedsięwzięcia, tj:

Uczeń jest przekonany:

- że człowiek powinien wykorzystać wszelkie możliwości dokształcenia i poszerzenia swych kwalifikacji;

- i stara się osiągnąć jak najlepsze wyniki w dziedzinie, którą się interesuje;

- szanuje ludzi innych wyznań i o innych poglądach;

- nie wstydzi się swego pochodzenia i wyznania.

Uczeń potrafi:

- na podstawie pakietów informacyjnych, stron internetowych wyszukać funkcjonujące obecnie programy edukacyjne UE, obejmujące nasz kraj i dotyczące bezpośrednio uczniów gimnazjów; 
- scharakteryzować możliwości, jakie daje każdy z wyżej wymienionych programów ze szczególnym uwzględnieniem tych, które dotyczą młodzieży w wieku gimnazjalnym (tzn. Comenius);

- wyjaśnić, w jaki sposób i w jakim celu można ubiegać się o pomoc finansową z konkretnych programów edukacyjnych.

\section{WNIOSKI KOŃCOWE}

Nauczanie podstaw przedsiębiorczości i edukacji europejskiej, zarówno w ramach przedmiotu, jak i w module stwarzają szanse na wykształcenie człowieka lepiej przygotowanego do życia w dynamicznie zmieniającym się świecie, odnajdywania się w różnorodnych sytuacjach, kooperowania z ludźmi odmiennymi od nas pod wieloma względami. Nadto, treści edukacji europejskiej na zajęciach z podstaw przedsiębiorczości oraz na ścieżkach edukacyjnych prowadzonych przez nauczycieli przedsiębiorczości niosą ze sobą duże możliwości zapewnienia przedmiotowi należnego mu miejsca w strukturze przedmiotów szkolnych i ugruntowania jego pozycji w planach nauczania. Edukacja europejska i podstawy przedsiębiorczości są bliskie w celach i spodziewanych osiągnięciach uczniów, mogą więc być skorelowane bardzo pozytywnie z punktu widzenia współczesnych zadań edukacji. Ich wspólnym polem jest m.in. dążenie do wypracowania aktywności, otwartości, tolerancji, zainteresowania otaczającym światem, łagodzenie barier mentalnych, niwelowanie stereotypów. Słusznie A. Suliborski (1991) podkreślał, iż nowoczesne i konkurencyjne wobec innych przedmiotów szkolnych zajęcia winny ograniczać funkcję informacyjną, a rozbudowywać funkcję wychowawczą i utylitarną.

Profesjonalna realizacja edukacji europejskiej i podstaw przedsiębiorczości w szkole jest możliwa wówczas, gdy prowadzi ją dobrze przygotowany nauczyciel. Dlatego pożądane jest obecnie uwzględnianie tych potrzeb $\mathrm{w}$ toku nauczycielskich studiów na kierunkach pokrewnych, np. na geografii i podejmowanie przez nauczycieli rożnych form dokształcania i doskonalenia zawodowego w tym zakresie.

W świetle przedstawionych rozważań należy stwierdzić, iż zapewnienie edukacji europejskiej znaczącego miejsca $\mathrm{w}$ zajęciach $\mathrm{z}$ podstaw przedsiębiorczości, stwarza dużą szansę na:

- prawidłowe realizowanie naczelnego celu kształcenia, tj. przygotowanie ucznia do dorosłego życia;

- prawidłowe realizowanie celów przedmiotowych w pożądanej hierarchii (od przekonań i postaw, umiejętności, rozumienia prawidłowości, po znajomość faktów);

- podnoszenie rangi podstaw przedsiębiorczości jako przedmiotu nauczania.

\section{LITERATURA I ŹRÓDŁA:}

Banach Cz., 1993. Kierunki zmian w polskiej szkole wobec integracji Europy. [w:] Szkoła i nauczyciel a integracja Europy (red. Gerlach R., Podoska-Filipowicz E.) WSP, Bydgoszcz

Banach Cz., 1999. Reforma systemu edukacji w Polsce - na tle tendencji europejskich. Nowa Szkoła, nr 9

Banach Cz., 2001. Strategia i zadania edukacji w integracji Polski z Europa [W:] Szkoła: edukacja europejska (red. Koprownicki J.). Wyd. Naucz. Nowe w Szkole, nr 5

Błeszyńska K., 2001. Problemy i dylematy edukacji dla wielokuturowości. [W:] Kultury tradycyjne a kultura globalna. Wyd. Trans Humana, Białystok, s. 111-125

Butryn D., 2001. A new shape of the European dimension in Poland during the education reform. [w:] International Conference on European Dimension of Teaching Geogra- 
phy in the Middle, South-Eastern and Eastern European Countries in Transition. Uniwersity of Maribor.

Dziennik Ustaw nr 61 z dnia 19 czerwca $2001 \mathrm{r}$.

Kalinowska -Witek B., 2000. Szkolnictwo i edukacja w Europie na przełomie XX $i$ XXI wie$k u$. Nowa Szkoła, nr 2

Licińska D., 1999. Słownik szkolny - człowiek i jego działalność. WSiP, Warszawa

Lipko S., 1973. Nauczanie geografii w okresie Komisji Edukacji Narodowej, PZWS, Warszawa

Makieła Z., 2004. Nowy przedmiot nauczania dla geografów - podstawy przedsiębiorczości [w:] Kształcenie i dokształcanie nauczycieli geografii w drodze do jednoczącej się Europy. Wyd. Nauk. AP, Kraków, s. 166-168

Olszewska-Dyoniziak B., 1991. Człowiek - kultura-osobowość. Wyd. Universitas, Kraków

Piróg D., 2002. Potrzeby i możliwości optymalizacji edukacji europejskiej na etapie gimnazjum (na przykładzie badań w wybranych gimnazjach województwa małopolskiego) rozprawa doktorska przechowywana $\mathrm{W}$ ZDG

Rabczuk W., 1994. Polityka edukacyjna Unii Europejskiej na tle przemian w szkolnictwie krajów członkowskich. IBN, Warszawa

Sielatycki M., 1993a. Edukacja europejska w nauczaniu geografii. Geografia w Szkole, nr 4

Sielatycki M., 1993b. Edukacja europejska w polskiej szkole. Problemy OpiekuńczoWychowawcze $\mathrm{nr} 2$

Sielatycki M., 1999. Europejski wymiar nauczania w zreformowanej geografii szkolnej. [w:] Problemy integracji europejskiej w nauczaniu geografii w zreformowanym systemie szkolnym (red. Kostrowicka A., Tomalkiewicz J.), UW, Warszawa

Sielatycki M., 2000. Europejski wymiar nauczania w polskich szkołach. [w:] Edukacja europejska w zreformowanej szkole (red. S. Bednarka) MEN, Wyd. DTSK Silesia, Wrocław

Suliborski A., 1991. Istota i funkcja geografii a system edukacji. [w:] Geografia w Szkole, nr 5, s. 272-275

Zioło Z., 2002. Model aktualizacji treści kształcenia geograficznego. [w:] Edukacja geograficzna w reformowanej szkole. Teoria i praktyka. Wyd. Nauk. AP, Kraków, s. 33-45 